\title{
The Relationship between Psychological Contract and Health among Organizational Citizenship Behavior
}

\author{
Sağllk Çalışanlarında Psikolojik Sözleşme ve Örgütsel Vatandaşlık Davranışı Arasındaki İlişki
}

\author{
Ahmet KARACA \\ Pamukkale University Civril Atasay Kamer Vocational School, Dept.of Foreign Trade, Turkey (akaraca@pau.edu.tr)
}

Keywords:
Psychological
Contarct
Organizational
Citizen
Membership
Health
Employee

Anahtar
kelimeler:
Psikolojik
Sözleşme Örgütsel
Vatandaşlık
Sağlık
Çalışan

\begin{abstract}
Psychological contract is expressed as mutual and variable psychological state as his speeches and unspoken expectations arising from perceptions and anticipations between the employee and management. Psychological contract is a concept based on mutual expectations and obligations between employers and employees of institutions. In organizational citizenship, a person makes sacrifices and self-sacrifices that are not specified in the person's duty and aims to provide the highest benefit to the institution. Organizational citizenship behaviors and psychological contracts are the ones should be investigated in professions where self-sacrificing work such as the health sector is essential. The aim of this research is to investigate the relationship between psychological contract and organizational citizenship behavior in health care workers. In this study, a questionnaire was applied to 133 persons selected from 4 private hospitals in Izmir and the results were re-evaluated in the SPSS program. It was determined that the average score of psychological contract violation points in the other profession group was higher than doctors and nurses.
\end{abstract}

\section{ÖZET}

Psikolojik sözleşme, çalışan ve yönetim arasındaki algı ve beklentilerden kaynaklanan, yazılmamış ve konuşulmamış beklentiler olarak, karşılıklı ve değişkenlik gösteren psikolojik bir durum olarak ifade edilmiştir. Psikolojik sözleşme kurumlardaki işveren ve çalışan arasında karşıllklı beklenti ve yükümlülükler üzerine kurulu olan bir kavramdır. Örgütsel vatandaşlıkta kişi görevinde belirtilmemiş fedakarlık ve özverileri de yapar ve bulunduğu kuruma en yüksek faydayı sağlamayı amaçlar. Sağlık sektörü gibi özverili çalışmanın esas olduğu mesleklerde örgütsel vatandaşlık davranışları ve psikolojik sözleşme araştırılması gereken konulardan biridir. Bu araştırmanın amacı Sağlık Çalışanlarında Psikolojik Sözleşme ve Örgütsel Vatandaşlık Davranışı arasındaki iliş̧iyi araştırmaktır. Bu araştırmada İzmir İlindeki 4 özel hastanede çalışanlar arasından seçilen 133 kişiye anket uygulanarak sonuçlar SPSS programında değerlendirilmiştir Araştırma sonucunda Diğer meslek grubunda olanların psikolojik sözleşme ihlali puan ortalamalarının doktor ve hemşirelerden daha yüksek olduğu belirlenmiştir. 


\section{INTRODUCTION}

\subsection{The definition and scope of the psychological contract}

The term psychological contract is first mentioned by Chester Barnard in 1938, and it is said that this term has been presented to the management literature in the meaning of "the need for employees to be convinced of loyalty to corporate goals in order to receive social, psychological and other rewards".

In the early years of the 1960s Argyris, Levinson, Price, Munden, Mandl, in 1962 Solley and in 1965 Schein has referred to psychological contract term (Morrison and Robinson, 1997).

Psychological contract in general means "the desire of the employee to exhibit a high level of work power for the organization, and constantly provision of job and promotion opportunities to the organization's employees by the organization" (Buranapin, 2007:16) But according to the changing circumstances and the demands of business research constantly appeared to be more than employment and promotion and wider framework; "work and administration, write, based on perception and demands between loss and hasn't expressed expectations that differ from mutual and as a psychological state" has been described as (Rowley, 1998).

A psychological contract is considered as the belief that mutual responsibilities between one's own and the other party (employee, company or individual). (Millward and Brewerton, 1999).

Psychological contract depends on a subjective criterion and individual perception. In management-employee relationship, the parties tend to believe that their wishes and what they promise to undertake are perceived in the same way as the other side. However, under no circumstances this agreement between parties is conceivable. So there is always a difference between the administration and the employer in terms of the demands and commitments. This difference is usually in the context of psychological contract (Schalk and Roe, 2007).

Briefly, the psychological contract (Rousseau, 2004);

- It is considered as a belief in the dual responsibility of the employee with the other party,

- A party in this relationship has made some promises to the other on the basis of dual aspect principle.

- $\quad$ Promises is completely subjective,

- However, the individual integrates his belief in the psychological contract with good intentions, fair attitudes, and trust factors, and associates his / her agreement with the main frame of the relationship with the other party.

\subsubsection{Types of psychological contract}

Psychological contract types can be classified as operational contract and relational contract.

\subsubsection{Operational contract}

The basis of the operational contract sets out short-term and specific contributions and supports with wide range of economic differences. In contrast, the relational contract is long-term contract without defined performance-award goals (Hui, Lee and Rousseau, 2004).

For employees with operational contracts, the organization is an institution that individuals benefit from and feel very little emotional commitment and loyalty for. For such workers, the organization is the institution that pursues daily awards and is the reference for the next job (Millward and Hopkins, 1998).

\subsubsection{Relational contract}

Relational contracts often involve issues that are more open-ended, ambiguous, and more difficult to interpret than potentially operational measures when the parties are inexperienced. Operational contracts can work in flexible and 
competitive organizations although in return for the relational contract the organization constitutes the basis for long-term loyalty exhibitions and organizational citizenship (Millward and Brewerton, 1999).

\subsection{The Concept of Organizational Citizenship}

Organizational citizenship behaviors are nowadays prevalent specifically in professions that require sacrifice.

\subsubsection{Definition of organizational citizenship behavior}

The term organizational citizenship behavior (OCB) is described as "individual behavior in the context of volunteering, which allows us to functionally function as a whole without regard for the formal reward system" (Organ, 1988). Organizational citizenship behavior is expressed as "individual behaviors that are not directly or explicitly expressed in the formal reward system, which are not compelling and allow the efficient and effective functioning of the organization to develop as a whole". Here, it means a job definition based on the people's own choices and they have no compelling influence on the persons (Podsakoff et al., 2000).

Organizational citizenship behavior is an attitude where the volunteerism is dominant even though one does not have a full duty in an organization and that benefits society positively, which will raise social importance. In relation with this statement, three qualities of organizational behavior are emerging. In the first place, the concept of voluntarism, namely, the tasks that are carried out completely within the scope of task definition, the second is the possible uncertainty of the opportunity for being rewarded for all efforts and achievements because it is not officially stated in the job description, and finally the efficiency of the organizational productivity plays a role in increasing the probability (Acar, 2006).

\subsubsection{The dimensions of organizational citizenship behavior}

Organizational citizenship behavior refers to attitudes of employees such as cooperation with colleagues, the enhancement of their productivity taking into account only the company's benefits, being respectful in communication with each other, and care for their work. In this way, the company is provided with a great benefit. Besides, Allowing for the emergence of attitudes in people with the benefit of the company. Organizational citizenship has different dimensions (Koster and Sanders, 2006). These are explained below.

\subsubsection{Altruism (Thinking of others)}

Altruist behavior includes attitudes to help each other, to volunteer for carrying each other's responsibilities in relation to work, to help other employees, and to prevent the emergence of work-related problems, in a way they will be beneficial to the organization they work. (Ölçüm, 2004: 20). People who have altruistic behaviors; in addition to attitudes that prevent the emergence of problems, they also perform comforting and supportive attitudes to their friends. The support that an employee gives to his or her friends who can not complete their work in time and who can not adapt themselves to their work is an example of altruistic behavior (Çelik, 2007).

The notion of altruism can be briefly explained in terms of all help behaviors considering how to support more in terms of potential, in relation to basis of the organization rather than his/her own. The main target here is the behavior in which the person is totally free, without feeling under pressure in any way (Sökmen, 2011).

\subsubsection{Courtesy}

The concept of courtesy is described as a necessary attribute for the communication that people in the organization need to use at the time when they take the decisions they will make as a result of their duties. It is a term describing the communication among the employees in the organization. Within the dimension of courtesy, people can warn each other not to make each other worse. Additionally within the scope of courtesy, it is important for the people who work for the decisions to be taken within the organization to inform each other, to provide information to those who will influence the situation to provide any negative condition, to respect each other and to recognize their general rights (Gürbüz, 2006). 


\subsubsection{Conscientiousness}

According to the Organ, conscientiousness is considered as the fact that some employees are more likely to get more into their roles than they undertake and to carry out more than demanded. It includes arrival on time in workplace, regular work, appropriate use the resting time, the appropriate attitudes. Persons adopt behaviors that can be deemed of conscientiousness by going beyond their agreement with what they are doing at work. Despite the administrators who will tolerate not coming to work due to adverse weather conditions or sickness, those employees who have a sense of conscientiousness show the attitude to continue their business in such conditions.

The main reason why the dimension of conscientiousness is considered as organizational citizenship behavior is that employees should volunteer to adhere to the rules. As employers adopt the rules, regulations and processes of the organization, it is considered as an act of organizational citizenship that they comply with the rules set by the organization without requiring any supervisory mechanism. (Podsakoff et al., 2000).

\subsubsection{Civil virtue}

Civil virtue includes involvement in the organization, support for organizational practices, and voluntary work in the organization, taking into account organizational benefits and objectives (Basım ve Şeşen, 2006). The civil virtue dimension also includes organization's work and structuring in order to participate in political life. Voluntary participation in organizational policy and decision-making stages and voluntary active participation in all events made in the organization reveal that organizational citizenship attitudes take place in the dimension of civil virtue. An example of civic virtue behavior is the ability of employees to work in ways that will benefit the vision of the organization (Organ, 1988).

\subsubsection{Sportsmanship}

The dimension of sportsmanship is defined as any negative situation that may occur in the working environment of the persons in the organization and avoidance from the attitudes that will cause tension. It underlines the necessity of not unnecessarily exaggerating problems and not constantly complaining. Respecting their colleagues, not exaggerating their problems unnecessarily, paying more attention to positive aspects than negative aspects, taking a constructive attitude towards problems related to the organization and playing a serious role in taking care of the organization's prestige. Sportsmanship behaviors can be evaluated as avoidance behaviors and predict that the people in the organization will move away from the negative attitudes that may cause any conflict or tension within the organization (Schnake and Dumler, 2003).

\subsection{Organizational Citizenship Relational Psychological Contract}

In the researches conducted, psychological contract, organizational commitment and citizenship behavior were examined together. A number of studies using various samples (Guzzo and Noonan, 1994; Johnson and O'Leary-Kelly, 2003; Lester, Turnley and Bloodgood, 2000) reveal that there is an inverse relationship between employee emotional attachment to the organization and psychological contract violation by the organization. In other words, an increase in the employee's commitment to the organization was observed when the institutions kept their promises to their employees high and met their expectations; the opposite resulted in the decrease in emotional attachment.

In the research conducted by Coyle-Shapiro and Kesler in 2003, the relationship between psychological contract and organizational commitment and organizational citizenship behavior were examined. The results of the research showed that public employees responded to the behavior of their employers (Coyle-Shapiro and Kessler, 2003)

\section{METHOD}

\subsection{Purpose of the research}

The purpose of this research is to investigate the relationship between psychological contract and organizational citizenship behaviors in health workers. 


\subsection{Universe sample}

Since the violation of organizational citizenship behavior and psychological contracts is important in the health sector and sampling is easily achieved, private hospitals in this sector have been selected. Employees working in 4 private hospitals in İzmir constitute the universe of research. The total number of employees in these private hospitals is 300 people. Among them, 133 people selected by random sampling method constitute the sample of the research.

\subsection{Collection of data}

The data used in the research were obtained via internet and by a face-to-face questionnaire exercised by the researcher himself. The data collection tools used in the research are as follows:

\section{The organizational citizenship scale}

Organizational Citizenship Behavior: Organizational citizenship behavior scale developed by Podsakoff, Mackenzie, Moorman and Fetter was used. "Organizational Citizenship Behavior Scale" developed by MacKenzie, Moorman and Fetter, and Moorman was used to measure. The organizational citizenship scale consists of 5 dimensions. These; Superior task awareness 1,2, 3, 4, 5. Questions; Sportsmanship: 6, 7, 8, 9, 10 Questions; Civil Virtue: 11, 12, 13, 14; Courtesy 15, 16, 17, 18, 19. Questions; Altruism: is calculated through questions 20, 21, 22, 23, 24.

\section{Psychological Contract Violation Scale}

"Psychological Contract Violation Scale" was used as one of the data collection tools. There are 9 items on the five-point Likert scale for 1 to 5 scoring items, including "1: I definitely agree" and "5: I definitely disagree" with the items on the psychological contract violation for the healthcare workers in the sample group. The scale of psychological contract compliance perception is based on 9 domains related to most managerial issues. These are the 9 potential psychological contract violence areas identified by Robinson and Rousseau (1994). The five-item scale is planned to measure the perceptions of the participants whether or not their employers have fulfilled their obligations to them.

\subsection{Analysis of the data}

Scale data in the study were entered into the SPSS program and coded. Descriptive statistics of sociodemographic variables and scale questions were made. Independent sample $t$ test and ANOVA analysis were used because of the normal distribution of the scales in order to investigate the differentiation between scale sub-dimensions and sociodemographic variables. The pearson corelation technique was used to examine the correlation between the scales.

\section{FINDINGS}

\subsection{Findings related to sociodemographic variables}

Table 1: Sex Distributions

\begin{tabular}{|l|l|l|}
\hline & $\mathrm{n}$ & $\%$ \\
\hline Men & 34 & 25,6 \\
\hline Women & 99 & 74,4 \\
\hline Total & 133 & 100,0 \\
\hline
\end{tabular}

$25.6 \%$ of the participants men, $74.4 \%$ women. 
Table 2: Age Distributions

\begin{tabular}{|l|l|l|}
\hline & $\mathrm{n}$ & $\%$ \\
\hline $18-24$ years & 15 & 11,3 \\
\hline $25-30$ years & 41 & 30,8 \\
\hline $31-36$ years & 36 & 27,1 \\
\hline 37 and over & 41 & 30,8 \\
\hline Total & 133 & 100,0 \\
\hline
\end{tabular}

$11.3 \%$ of the participants are in the age range of $18-24,30.8 \%$ are $25-30,27.1 \%$ are $31-36,30.8 \%$ are 37 years and over.

Table 3: Distribution of marital status

\begin{tabular}{|l|l|l|}
\hline & $\mathrm{n}$ & $\%$ \\
\hline Married & 65 & 48,9 \\
\hline Single & 68 & 51,1 \\
\hline Total & 133 & 100,0 \\
\hline
\end{tabular}

$48.9 \%$ of the participants married and $51.1 \%$ single.

Table 4: Distributions of educational status

\begin{tabular}{|l|l|l|}
\hline & $\mathrm{n}$ & $\%$ \\
\hline High school & 23 & 17,3 \\
\hline University & 78 & 58,6 \\
\hline Master / Doctorate & 32 & 24,1 \\
\hline Total & 133 & 100,0 \\
\hline
\end{tabular}

$17.3 \%$ of those who participated in the study had graduated from a law school, $58.6 \%$ were graduated from university, and $24.1 \%$ were graduated from a master / doctoral degree.

Table 5. Professions distribution

\begin{tabular}{|l|l|l|}
\hline & $\mathrm{n}$ & $\%$ \\
\hline Specialist & 4 & 3,0 \\
\hline Practitioner Doctor & 5 & 3,8 \\
\hline Nurse & 98 & 73,7 \\
\hline Other & 26 & 19,5 \\
\hline Total & 133 & 100,0 \\
\hline
\end{tabular}

$3.0 \%$ of the participants specialists, $3.8 \%$ practitioners, $73.7 \%$ nurses and $19.5 \%$ other professions.

Table 6: Organizational Citizenship Scale descriptive statistics

\begin{tabular}{|l|l|l|l|l|l|}
\hline & \multicolumn{1}{|c|}{$\mathrm{N}$} & \multicolumn{1}{c|}{ Min } & \multicolumn{1}{c|}{ Max } & \multicolumn{1}{c|}{ Average } & \multicolumn{1}{c|}{$\begin{array}{c}\text { Standard } \\
\text { deviation }\end{array}$} \\
\hline $\begin{array}{l}\text { Superior } \\
\text { awareness }\end{array}$ & 133 & 2,00 & 5,00 & 4,0120 &, 59072 \\
\hline Sportsmanship & 133 & 1,00 & 4,80 & 1,7383 &, 80234 \\
\hline Civil virtue & 133 & 1,50 & 5,00 & 4,0414 &, 69779 \\
\hline Courtesy & 133 & 2,80 & 5,00 & 4,4271 &, 49100 \\
\hline altruism & 133 & 2,75 & 5,00 & 4,2744 &, 60056 \\
\hline Valid N (listwise) & 133 & & & & \\
\hline
\end{tabular}


According to the examination of the descriptive statistics of the Organizational Citizenship Scale, it is seen that the highest average dimension is the courtesy dimension and the lowest average is the sportsmanship dimension.

Table 7. Psychological Contract Scale descriptive statistics

\begin{tabular}{|l|l|l|l|l|l|}
\hline & N & Min & Max & Average & $\begin{array}{c}\text { Standard } \\
\text { deviation }\end{array}$ \\
\hline Psyhcological_contract_violation & 133 & 1,00 & 5,00 & 2,9398 &, 75005 \\
\hline
\end{tabular}

According to the examination of descriptive statistics of the Psychological Contract Scale, the psychological contract violation dimension value is calculated as (Average: 2.93). We can note that psychological contract violation perception is moderate.

Table 8: Psychological contract violation differentiation according to the profession variable

\begin{tabular}{|l|l|l|l|l|l|}
\hline & N & \multicolumn{1}{|l|}{ Average } & $\begin{array}{c}\text { Standard } \\
\text { deviation }\end{array}$ & F & p \\
\hline Specialist & 4 & 2,2222 & 0,00000 & & \\
\cline { 1 - 3 } Practitioner Doctor & 5 & 2,6889 &, 43319 & \multirow{2}{*}{5,423} & \multirow{2}{*}{002} \\
\cline { 1 - 3 } Nurse & 98 & 2,8617 &, 77245 & & \\
\cline { 1 - 4 } Other & 26 & 3,3932 &, 54090 & & \\
\hline Total & 133 & 2,9398 &, 75005 & & \\
\hline
\end{tabular}

There is a significant difference between professions variable and psychological contract violation dimension $(\mathrm{p}<0.05)$. Psychological contract violation averages of those who are in other profession group are higher than others.

Table 9.Post Hoc Multiple Comparison Table

\begin{tabular}{|c|c|c|c|c|c|}
\hline \multicolumn{3}{|c|}{ Profession : } & $\begin{array}{c}\text { Average } \\
\text { difference }\end{array}$ & $\begin{array}{c}\text { Standard } \\
\text { error }\end{array}$ & $\mathrm{p}$ \\
\hline \multirow[t]{12}{*}{$\begin{array}{l}\text { Tukey } \\
\text { HSD }\end{array}$} & \multirow[t]{3}{*}{ Specialist } & $\begin{array}{l}\text { Practitioner } \\
\text { Doctor }\end{array}$ &,-- 46667 & ,47962 & ,765 \\
\hline & & Nurse &,- 63946 & ,36471 & ,301 \\
\hline & & Other & $-1,17094 *$ & ,38400 & 015 \\
\hline & \multirow[t]{3}{*}{ Practitioner Doctor } & Specialist & ,46667 & ,47962 & ,765 \\
\hline & & Nurse &,- 17279 & ,32780 & ,952 \\
\hline & & Other &,- 70427 & ,34914 &, 187 \\
\hline & \multirow[t]{3}{*}{ Nurse } & Specialist & 63946 & ,36471 & ,301 \\
\hline & & $\begin{array}{l}\text { Practitioner } \\
\text { Doctor }\end{array}$ & , 17279 &, 32780 & ,952 \\
\hline & & Other &,$- 53148^{*}$ &, 15773 &, 005 \\
\hline & \multirow[t]{3}{*}{ Other } & Specialist & $1,17094 *$ & ,38400 & ,015 \\
\hline & & $\begin{array}{l}\text { Practitioner } \\
\text { Doctor }\end{array}$ & ,70427 & ,34914 & ,187 \\
\hline & & Nurse & ,53148* & ,15773 &, 005 \\
\hline
\end{tabular}

Significant differences were found between psychological contract violation scores of those who were in the other profession group and those who were specialists $(\mathrm{p}<0,05)$. Psychological contract violation scores of other occupational groups are higher than those of specialist doctors. Significant differences were observed between psychological contract violation scores of those who were in the other profession group and nurses ( $\mathrm{p}<0,05)$. Psychological contract violation scores of other occupational groups are higher than those of specialist doctors. 
Table 10: Relationship between Psychological Contract and Organizational Citizenship

\begin{tabular}{|c|c|c|c|c|c|c|c|}
\hline & & 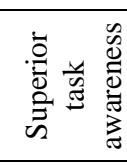 & 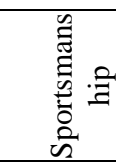 & $\stackrel{\stackrel{0}{Z}}{\stackrel{0}{3}}$ & 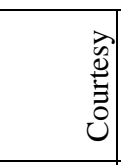 & 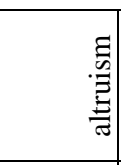 & 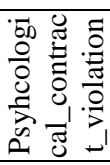 \\
\hline \multirow[t]{3}{*}{ Superior task awareness } & PearsonCorrelation & 1 &, $190 *$ &, $374 * *$ & ,005 & ,123 &, 002 \\
\hline & Sig. (2-tailed) & &, 028 &, 000 & ,953 & ,158 & 982 \\
\hline & $\mathrm{N}$ & 133 & 133 & 133 & 133 & 133 & 133 \\
\hline \multirow[t]{3}{*}{ Sportsmanship } & PearsonCorrelation &, $190 *$ & 1 &,$- 190 *$ &,- 139 &,- 072 &,- 023 \\
\hline & Sig. (2-tailed) &, 028 & &, 029 &, 111 &, 413 & ,793 \\
\hline & $\mathrm{N}$ & 133 & 133 & 133 & 133 & 133 & 133 \\
\hline \multirow[t]{3}{*}{ Civil virtue } & PearsonCorrelation &, $374 * *$ &,$- 190 *$ & 1 &, $289 * *$ &, $553 * *$ & ,018 \\
\hline & Sig. (2-tailed) &, 000 &, 029 & & ,001 &, 000 & 837 \\
\hline & $\mathrm{N}$ & 133 & 133 & 133 & 133 & 133 & 133 \\
\hline \multirow[t]{3}{*}{ Courtesy } & PearsonCorrelation & ,005 &,- 139 & ,289** & 1 &, $375 * *$ & 010 \\
\hline & Sig. (2-tailed) & ,953 & ,111 &, 001 & &, 000 & ,910 \\
\hline & $\mathrm{N}$ & 133 & 133 & 133 & 133 & 133 & 133 \\
\hline \multirow[t]{3}{*}{ altruism } & PearsonCorrelation & ,123 &,- 072 &, $553 * *$ & ,375** & 1 & ,099 \\
\hline & Sig. (2-tailed) & ,158 & ,413 & ,000 & ,000 & & ,259 \\
\hline & $\mathrm{N}$ & 133 & 133 & 133 & 133 & 133 & 133 \\
\hline \multirow{3}{*}{$\begin{array}{c}\text { Psychological contract } \\
\text { violation }\end{array}$} & PearsonCorrelation & ,002 &,- 023 & ,018 &, 010 & ,099 & 1 \\
\hline & Sig. (2-tailed) & ,982 & ,793 & ,837 & ,910 & ,259 & \\
\hline & $\mathrm{N}$ & 133 & 133 & 133 & 133 & 133 & 133 \\
\hline
\end{tabular}

A positive correlation was determined between the superior task conscientiousness score average and the sportsmanship and civil virtue subscale. A negative correlation was determined between the average of sportsmanship and civil virtue subscale. A positive correlation was determined between civil virtue score averages and courtesy and altruism subscales. A positive correlation was determined between the courtesy score average and the altruism subscale.

\section{RESULT}

Organizational citizenship behavior is an attitude where the volunteerism is dominant even though one does not have a full duty in an organization and that benefits society positively, which will raise social importance.

Especially the presence of organizational citizenship behavior in the health sector increases the quality of service and customer satisfaction.

In this study, it was determined that the organizational citizenship scores of the health workers were higher than the sportsmen dimension. Organizational citizenship behaviors are generally found to be at a high level in health workers. It was determined that organizational citizenship behavior did not differ according to sociodemographic variables. As a result of the analyzes undertaken to investigate the variation of the psychological contract violation scale according to the sociodemographic variables, only a significant difference was observed between them and the professions variable. Psychological contract violation score averages of those who are in other profession group are higher than doctors and nurses. It was found that there was a significant positive correlation between the organizational citizenship behavior subscales and no significant correlation between psychological contract violation scale and organizational citizenship behavior subscales.

Due to the fact that nursing and doctorship require self-sacrifice, they are professions with organizational citizenship. Doctors and nurses are people who devote themselves to their profession. Therefore, psychological contract perception may be lower than other professions. 
In this research, we propose the followings in the light of these results:

- $\quad$ Psychological contract violations should be prevented in the field of health.

- The rights of health workers who fulfill important services under intense working conditions must be respected.

- Health workers are also required to fulfill the tasks expected from them.

- $\quad$ Research should be carried out to determine the expectations of health workers.

- Health workers need to be trained within the awareness of their duties and responsibilities.

\section{REFERENCES}

ACAR, A.Z. (2006). “Örgütsel yurttaşlık davranışı: kavramsal gelişimi ile kişisel ve örgütsel etkileri”. Dogus University Journal, 7 (1), pp.1-14.

BASIM, H. N. ve ŞEŞEN H. (2006), "Örgütsel Vatandaşlık Davranışı Ölçeği Uyarlama ve Karşılaştırma Çalışması", Ankara Üniversitesi Siyasal Bilgiler Fakültesi Dergisi, Vol.: 61, No. 4, pp. 1-22.

BURANAPIN, S. (2007). "PsychologicalContractAlignmentandCareerEffectivenessunder a RadicalOrganizationalChange: A Case of Chiang Mai University ". Boston: BostonUniversityPress.

COYLE-SHAPIRO J. \& KESSLER, I. (2000). Consequences of the Psychological Contract for the Employment Relationship: A Large Scale Survey. Journal of Management, 37, 903-930

ÇELIK, M. (2007). “Örgüt kültürü ve örgütsel vatandaşlık davranışı bir uygulama”. Unpublished Doctorate Thesis, Institute of Social Sciences, Ataturk University, Erzurum.

DEMİRCI, K., ERBAŞ, A. \& GIDERLER A.C. (2009). "Üniversite öğrencilerinin stk’lara katılım potansiyellerinin örgütsel vatandaşlık davranışı boyutlarından sivil erdem boyutu çerçevesinde incelenmesi”. KhazarUniversityPress, 12 (1-2), pp. 752-76.

GUZZO, R., A., NOONAN, K. A., \& Elron, E. (1994). Expatriate managers and the psychological contract. Journal of Applied Psychology, 79: 617-626.

GÜRBÜZ, S. (2006). “Örgütsel vatandaşlık davranışı ile duygusal bağlılık arasındaki ilişkilerin belirlenmesine yönelik bir araştırma”. Ekonomik ve Sosyal Araştırmalar Dergisi, 3 (1), pp. 48-75.

KOSTER, F., STOCKMAN, F., HODSON, R. and SANDERS, K. (2007). "Solidaritythroughnetworks: theeffects of taskandinformalinterdependence on cooperationwithinteams". EmployeeRelations, pp. 117-137.

LESTER, S. W., TURNLEY, W. H., BLOODGOOD, J. M. \& BOLINO, M. C. (2002). Not Seeing Eye to eye: Differences in supervisor and subordinate perceptions of attributions for psychological contract breach. Journal of Organizational Behavior, 23: 39-56.

MILLWARD, L. J. \& HOPKINS L. J. (1998). "PsychologicalContracts, OrganizationalandJobCommitmen" t. Journal of Applied Psychology, 28(16), 1532.

MILLWARD, L. J. \& BREWERTON, P.M. (1999). "Contractorsandtheirpsychologicalcontracts". British Journal of Management, 10, 256

MORRISON, E. W. \& Robinson. S. (1997). "Whenemployeesfeelbetrayed: A Model of How PsychologicalContractViolationDevelops ". Academy of Management Review, 22 (1), 226-256.

ORGAN, D. W. (1988). “Organizationalcitizenshipbehavior: Thegoodsoldiersyndrome. Lexington”, MA: LexingtonBooks 
ÖLÇÜM Ç. M. (2004). “Örgütsel Vatandaşlık Davranışı”, 1. Edition, Nobel Yayın Dağıtım, Ankara.

PODSAKOFF, P. M., MACKENZIE, S.B. \& BOMMER, W.H. (1996). "TransformationalLeaderBehaviorsandSubstitutes as Determinants of EmployeeSatisfaction, Commitment, TrustandOrganizationalBehaviorCitizenshipBehaviors". Journal of Management, 22 (2), pp. $259-298$.

PURVIS, L. J.\& M. Cropley (2003). "Psychologicalcontracting: processes of contractingduringintervaliesbetweennanniesandtheir employers", Journal of Occupational and Organizational Psychology, 76, pp. ,213- 241

ROBINSON, S. L. \& ROUSSEAU D. M. (1994). "Violatingthepsychologicalcontract: Not theException but the Norm ". Journal of Organizational Behavior, 15 (3), 256.

ROWLEY, J. (1998). "QualityMeasurement in ThePublicSector: SomePerspectivesFromThe Services QualityLiterature ". Total Quality Management, 9 (2-3), 330-331.

SAYLI, H. (2006). “Örgüt ve Örgütsel Vatandaşl1k II”, http://www.ikademi.com/orgutsel-davranis/1103-orgut-veorgutsel-vatandaslik-ii.html.

SCHALK, R. \& ROE, R. (2007). “Towards a Dynamic Model of PsychologicalContractViolation”. Oxford: Executive Management Committee / Blackwell Publishing Ltd.

SCHNAKE, M.E. \& DUMLER, M.P. (2003). "Levels of measurementandanalysisissues in organizationalcitizenshipbehaviorresearch". Journal of Occupational and Organizational Psychology, (76), pp. 283 -301 .

SÖKMEN A. \& BOYLU Y., (2011). "Örgütsel Vatandaşlık Davranışı Cinsiyete Göre Farklılık Gösterir Mi? Otel İşletmeleri Açısından Bir Değerlendirme”, Gazia 